\title{
Case study: the strengthening and seismic safety of the Oni synagogue in Georgia
}

\author{
M. Danieli ${ }^{1} \&$ A. Aronchik ${ }^{2}$ \\ ${ }^{1}$ Department of Civil Engineering, Ariel University, Israel \\ ${ }^{2}$ Ring Engineering Ltd., Azour, Israel
}

\begin{abstract}
On April 29, 1991, there was an earthquake in northern Georgia, Caucasus, its magnitude by Richter scale being $\mathrm{Ms}=6.9$. Several buildings having architectural and historic importance including the synagogue in Oni were damaged by the earthquake. The synagogue was completed in 1895. It is a rectangular symmetrical structure $(18.5 \times 14.9 \mathrm{~m})$ built of local stone, its maximum height being $15 \mathrm{~m}$. The distance from the synagogue to the earthquake epicentre was 25 to $30 \mathrm{~km}$. The earthquake caused substantial damage to the synagogue building. Cracks developed in all bearing elements, such as arches, the shell, walls, and in the drum. Some structures, mainly console structures, collapsed. Preserving architectural-historical monuments in their original state is one of the responsibilities of a civilized society. Retrofitting of these structures was completed two years later. Permanent conservation was aimed primarily at strengthening walls, arches, corner vaults, portico, stele, sculptures, drum, etc. On September 8, 2009, there was another earthquake in northern Georgia. The magnitude in the earthquake epicentre which was $12 \mathrm{~km}$ from Oni was 6.2. The building of the synagogue in Oni survived this earthquake without any substantial damage caused. It has proved the effectiveness of the strengthening works in these buildings performed by us. In this paper we analyze the seismic behaviour of the synagogue in Oni before and after its strengthening. The seismic behaviour of the building was investigated using FEM. The results of such an analysis given here correspond closely enough to the behaviour of the building during the earthquake. We developed and applied an original method of expert estimation of the earthquake resistance of buildings. Methods and
\end{abstract}


techniques offered and applied for retrofitting the synagogue in Oni may be recommended for the strengthening and conservation of other historic structures. Keywords: historical building, seismic behaviour, damaged, strengthening.

\section{Introduction}

Many heritage buildings as a structural and architectural element have utilitarian value. Numerous ancient buildings, although not as large as the Pantheon or the Hagia Sophia, can be also of certain value in historical, architectural, and engineering aspects. The evaluation of a building in these aspects predetermines the significance of its preservation. In addition, a possibility of its utilization is to be considered.

Built mostly centuries ago, heritage buildings often need restoration and strengthening, especially in seismic regions. Preserving architectural-historical monuments in their original state is one of the responsibilities of a civilized society. At the end of the XIX century, the new material, the reinforced concrete, having good compression and tension resistance capacity began to oust stone constructions. It has to be noted that concrete retains its properties for a long period of time; for example, the dome of the Pantheon of Rome was constructed of concrete 2000 years ago [1]. For strengthening or conservation of Historic Heritage different traditionally and modern methods and principles can be used ([2-7] etc.). Their study and summarizing are important.

On April 29, 1991 there was an earthquake in northern Georgia, Caucasus. Magnitude by Richter scale was Ms $=6.9$. Several historical buildings, including a synagogue in Oni, were damaged by the earthquake. This paper deals with the example of restoration and strengthening a synagogue in Oni and analysing the seismic behaviour of the building of the synagogue before and after its strengthening.

\section{Synagogue in Oni}

\subsection{Building of synagogue}

The synagogue was completed in 1895 . It is a rectangular symmetrical structure $(18.5 \times 14.9 \mathrm{~m})$ built of local stone, its maximum height being $15 \mathrm{~m}$ (Fig. 1).

The dome, built of the same stone, has the $6.7 \mathrm{~m}$ span and the $3.0 \mathrm{~m}$ rise. It is situated in the centre of the structure, atop a drum, which is supported by arches. The ceiling in the corners is surmounted vaults. The rectangular inner structure, on its four sides has a flat ceiling on wooden beams. The beams, as the vaults, are situated atop outer walls and inner arches. The dome, drum and vaults built of the same stone. A cement-lime mortar was used for construction. The arches in the plan are located on mutually perpendicular directions. They are situated atop four stone columns symmetrically located inside the building and atop inner pilasters of the outer walls. The arches are tied at their bottom by steel rods with square cross section $(25 \times 25 \mathrm{~mm})$, for taking horizontal tensile forces.

There is a stele (a stone plate covered with inscriptions) on the parapet of the frontal facade, and there are sculptural forms in all four corners of the building. 

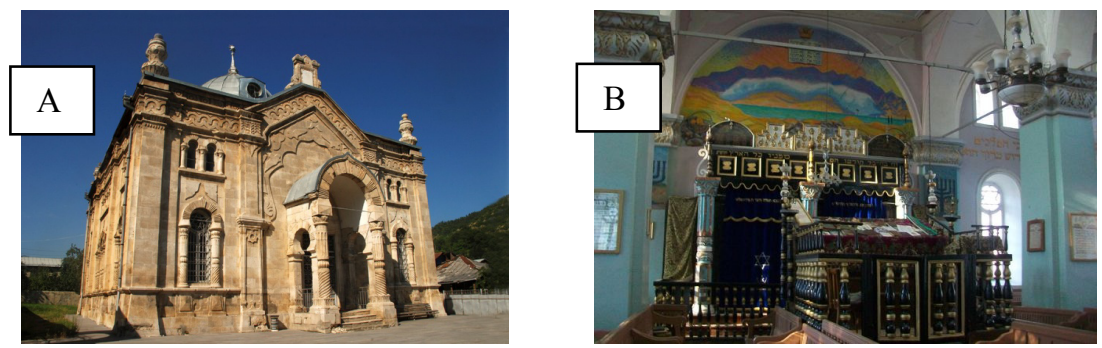

Figure 1: The synagogue in Oni after the strengthening and restoration: A - general view; B - interior.

The stele and sculptures are made of separate stones connected to each other by metal staples. Portico of the building is made of stone columns covered by stone vault. The columns are made of separate stones. Their bottoms are tied on the edges by metal tie bars, and rear columns of the portico are connected with the building by metal staples, located in the body of the vault and preventing free horizontal shift of the portico's structures. At present it is an architecturalhistorical monument of Georgia.

\subsection{Seismic situation of the building location}

The building of the synagogue in Oni is located in an active seismic zone in North Georgia, Caucasus. On April 29, 1991 there was an earthquake in northern Georgia. Magnitude of the earthquake in Racha, Georgia, on April 29, 1991 by Richter scale according to the accepted estimations was Ms $=6.9$. This magnitude corresponds to the intensity of $\mathrm{I}_{0}=9.5$ on the MSK-64 twelve-step scale. Several thousands of aftershocks were registered later on, during four months. Their magnitudes varied between $\mathrm{M}=6.2$ and $\mathrm{M}=5.3$, being sometimes almost as powerful as the primary shock. The following chart (Fig. 2) illustrates this situation [7].
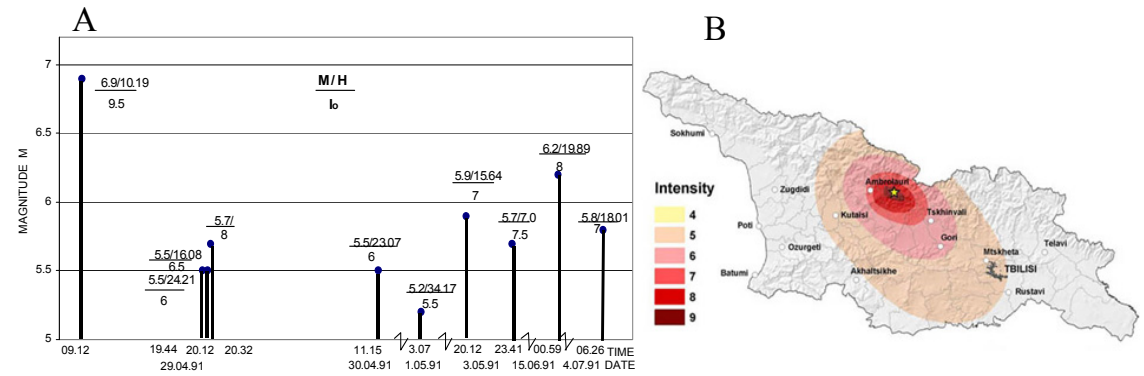

Figure 2: Seismic situation caused by the earthquake in Racha, Georgia, between April 29 and July 04, 1991, in the epicenter: A - diagram: $\mathrm{M}$ - Richter magnitude; $\mathrm{H}$ - focus depth, $\mathrm{km} ; \mathrm{I}_{\mathbf{0}}$ - intensity on MSK-64 scale; B - calculated earthquake intensity map. 


\subsection{Damage of the buildings}

Over 46 thousand buildings were damaged or destroyed. Several historical buildings, like a synagogue in Oni, damaged an earthquake which occurred in Racha, Georgia, on April 29, 1991 [8]. The distance from synagogue in Oni to the earthquake epicenter was $25-30 \mathrm{~km}$. The measured intensity was $\mathrm{a}=2 \mathrm{~m} / \mathrm{sec}^{2}$.

The earthquake caused substantial damage to the building, which did not collapse, however, due to its symmetrical structure, rigid walls, steel ties, and small arch spans. Overall views of the building after earthquake are presented in Figure 3A. Cracks developed in actually all bearing elements, such as arches, shell, external walls, and in the drum (Fig. 4). The crack opening in the arches was $5-10 \mathrm{~mm}$. Many architectural elements and sculptures situated outside, at the facades, were severely damaged. Some of them collapsed, including fragments of walls (Fig. 3).
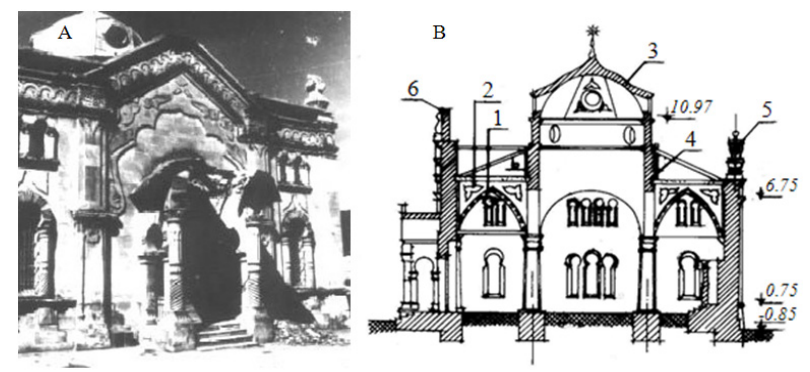

Figure 3: The synagogue in Oni: A - view after the earthquake; $\mathrm{B}$ - the cross section: 1 - arch; 2 - ceiling; 3 - dome; 4 - drum; 5 - collapsed sculpture; 6 - collapsed facade element; 7 - collapsed portico.

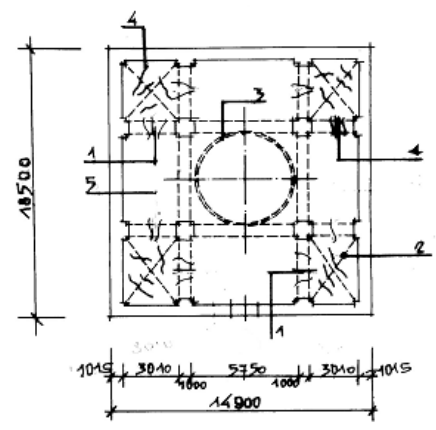

Figure 4: Plafond plan with the cracks shown: 1 - arch; 2 - surmounted vaults ceiling; 3 - dome; 4 - cracks; 5 - wooden ceiling. 


\subsection{Estimation of buildings seismic resistance}

A method for estimation of structural seismic resistance [9-11] was applied to this building [12]. The estimated earthquake resistance level of a building Eer, according to its definition, equals the difference between the values of Rer - the required earthquake resistance level and Ser - the estimated shortage of earthquake resistance. The value of Ser is determined depending on the value of the relative earthquake resistance coefficient of the Building Ker. The Coefficient Ker was estimated based on the design data and the results of the inspection. The value of the coefficient $\mathbf{K e r}=0.802$. All analytical and numerical data in this paragraph are taken from [12]. Correspondingly, the value of the estimated shortage of earthquake resistance Ser $=0.02647$.

The estimated earthquake resistance level of a building:

$$
\text { Eer }=\text { Rer }- \text { Ser }=0.200-0.0265=0.1735<0.200,
$$

where: $\operatorname{Rer}=0.200$ corresponds to $\mathbf{Z}=0.200$. $\mathbf{Z}$ - is the coefficient of the ground's predicted horizontal acceleration; it is defined by $\mathbf{Z}=\mathbf{a}_{h \max } / \mathbf{g}$, where $\mathbf{a}_{h \max }$ is the maximum predicted horizontal acceleration of the ground and in this case $\mathbf{a}_{h \max }=2.0 \mathrm{~m} / \mathrm{s}^{2} ; \mathbf{g}=9.81 \mathrm{~m} / \mathrm{s}^{2}$ is the gravity acceleration.

According to the estimate presented, because Eer $=0.1735<\mathbf{Z}=0.200$, as mentioned above, the building tested does not meet the required earthquake resistance level. In order to increase the earthquake resistance of any given building repairing and strengthening of the building is required. It should be noted that this estimation was done in view of significant post-earthquake damage and is, in a sense, subjective. The estimation done shows the most vulnerable (in the sense of seismic resistance) elements such as stone sculptures and a stele made of the local stone. It may be useful for adopting the right strategy for developing the strengthening project [13].

\subsection{Conservation of the building}

Temporary conservation of the building after earthquake has not been carried out. Despite this, further damage to the drum and the dome during the aftershock period did not occur. Retrofitting of these structures was completed two years later. Permanent conservation (authors of the project of conservation of the Synagogue complex-architect are Prof. S. Bostanashvili and structural engineer Dr. M. Dinielashvili) was aimed primarily at strengthening of bearing walls, arches, corner vaults, portico, stele, sculptures, drum, etc. (Fig. 1). The project included the following major steps [8]:

- Removal of plaster, thorough cleaning, and filling of cracks with cement-lime mortar. Steel wedges were used to control complete filling of wide cracks (>6 mm).

- Reinforced plastering of arch and shell surfaces in damaged areas. One layer of steel meshes $(150 \times 150 \mathrm{~mm})$ of $\varnothing 6 \mathrm{~mm}$ wires served as reinforcement. The meshes were tied to $ø 10 \mathrm{~mm}$ steel anchors, each situated in a pre-drilled hole 
at a $30^{\circ}$ angle to the surface (Fig. 6). Cement - lime mortar was applied $\left(\mathrm{f}_{\mathrm{ck}}=10 \mathrm{MPa}\right)$, so that the layer thickness was $40 \mathrm{~mm}$.

- Strengthening of the drum. Thin 10x10 mm mesh of ø1 mm wires was used for external reinforcement. Cement lime mortar $\left(f_{\mathrm{ck}}=10 \mathrm{MPa}\right)$ was applied to provide a $30 \mathrm{~mm}$ layer.

- Restoration of non - bearing external parts and architectural elements of the building, using similar techniques.

Details of strengthening are shown in Figure 5. As a result of the strengthening the capacity bearing of the above structures elements and seismic resistance became higher than they were before the earthquake.

A

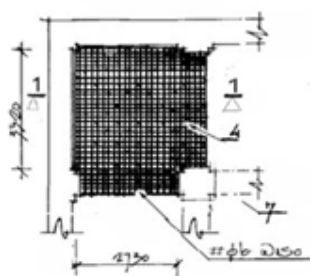

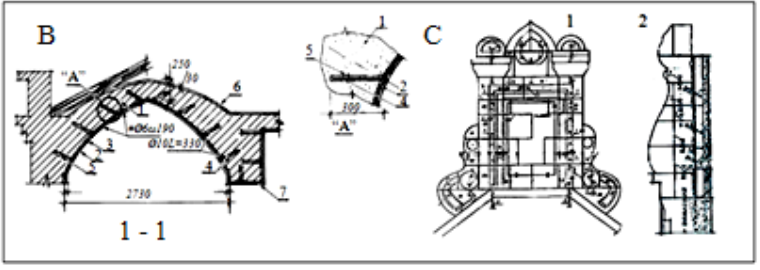

Figure 5: Details of strengthening (dimensions in $\mathrm{mm}$ ). A, B - details of arches and vaults reinforcement: 1 - arch; 2 - reinforced plastering layer; 3 -steel mesh; 4 -drilling; 5 - steel anchor C - strengthening of the frontal stele: 1 - frontal facade; 2 - lateral facade

\section{Numerical structural analyses}

\subsection{Description}

The numerical structural analysis is made using the FEM. The structural analysis was made using software "SCADA" and "LIRA" (Finite Element Package, France - Ukraine, International certificate of checking - IMS CONSEIL, June, 1992). The series of numerical structural analyses included:

1. Dynamic analyses for the space model of the whole structure. These analyses were linear and were aimed at a preliminary determination of seismic forces and their distribution among the main bearing elements of a building. The model of the whole structure consisted of the groups of finite elements of various kinds. Rod finite elements were used for columns, arches and iron tie-rods; plateand, shell- (triangular and rectangular) and volume-type (triangular prism) finite elements were used for description of stone walls and vaults.

2. Calculation of seismic forces and their distribution among main bearing elements of a building on the basis of a modal analysis. The analysis was made separately in two mutually perpendicular directions $\mathrm{X}$ and $\mathrm{Y}$ (direction $\mathrm{X}$ is parallel to the frontal facade; $Y$ direction is perpendicular to the frontal facade). When making these analyses, the horizontal acceleration of the ground was taken to be $\mathrm{a}=1 \mathrm{~m} / \mathrm{sec}^{2}$. According the estimations the actual acceleration was $\mathrm{a}=2$ 
$\mathrm{m} / \mathrm{sec}^{2}$. That is why the numerical results received (see drawings and tables) should be multiplied by two. In the table the predicted acceleration factor $\mathbf{Z}=\mathrm{a} / \mathrm{g}$, where $\mathbf{g}$ is the gravity acceleration.

3. Series of static physically non-linear analyses for the most loaded and specific elements of the building: corner vaults and frontal façade. The analyses took into account the following combination of loads: the dead load, live load and seismic load. Values of seismic forces were taken according to the results of the first series as a group of seismic forces. They were applied as concentrated forces.

Input data for analysis of seismic resistance of walls, arches and vaults was drawn from results of inspection and measures and according to the design data. Masonry of local stone on cement-lime mortar of the middle strength; density $1.8 \mathrm{t} / \mathrm{m}^{3}$; module of deformations $\mathrm{E}=1.2 \mathrm{E} 4 \mathrm{~kg} / \mathrm{cm}^{2}$; strength of compression $\mathrm{Rc} \approx 1.2-1.5 \mathrm{MPa}$, strength of tension $\mathrm{Rt} \approx 0.18-0.2 \mathrm{MPa}$.

\subsection{Some results of structural analysis and discussion}

The main results of structural analysis under the action of seismic forces are presented in Figures 6-12 and Table 1. When considering the figures and tables above we can see that the analyses given reflect the behavior of a building during an earthquake. In Figure 6 we can clearly see how much bigger are the displacements of the stele on the frontal wall. We can also see the concentration of the high-level stress at the base of the stele. Cracks in walls and corner vaults, destructions in the stele and shift of sculptures correspond to the results received. The behavior of iron tie-rods of arches should be specially noted. The stress is changeable: tension - compression. The tension strength of iron tie-rods is sufficient. For the compression the stability of the tie-rods can be explained by an instant change of seismic forces directions as well as by sufficient compression strength of arches (see Table 1).

Separate analysis to determine seismic resistance of decorative elements (sculptures) under the action of the dead load. The analysis was made for a single console cylinder rod $1.0 \mathrm{~m}$ high and $0.6 \mathrm{~m}$ in diameter. Seismic force is distributed uniformly height-wise as concentrated horizontal forces. Horizontal acceleration of the ground is $\mathrm{a}=2 \mathrm{~m} / \mathrm{sec}^{2}$. According to the norms [14], an

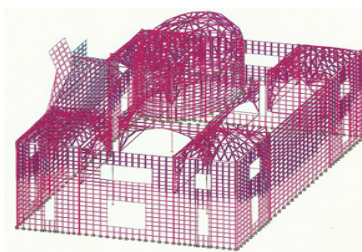

Figure 6: Second mode shape in $\mathrm{Y}$ direction.

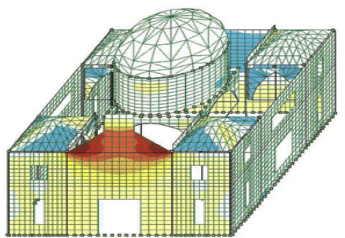

Figure 7: Bending moments in $\mathrm{Y}$ direction. 


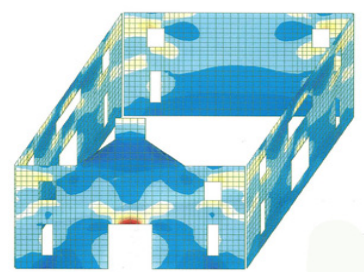

Figure 8: Bending moments in the walls in $\mathrm{X}$ direction.
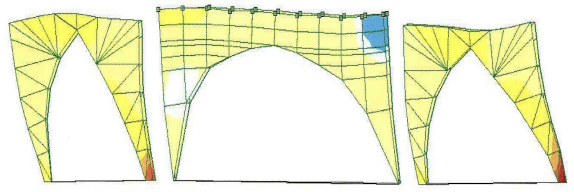

Figure 10: Principal stresses in the arches in $\mathrm{X}$ direction.

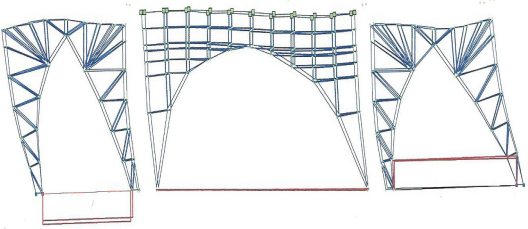

Figure 11: Normal forces (tensioncompression) in iron tierods in $\mathrm{X}$ direction.

B

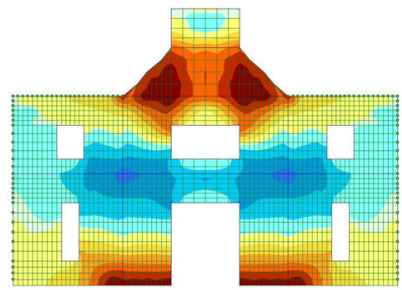

A

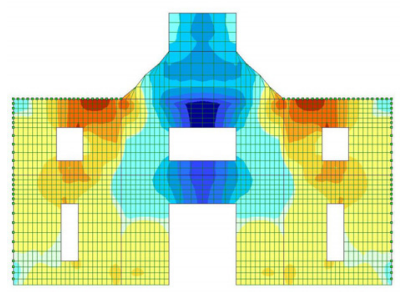

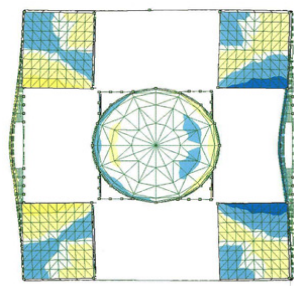

Figure 9: Bending moments in the vaults in $\mathrm{X}$ direction

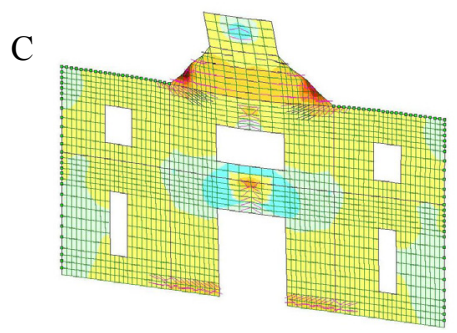

Figure 12: Non-linear analyses of frontal walls: A - Bending moments in $\mathrm{X}$ direction; $\mathrm{B}$ - Bending moments in $\mathrm{Y}$ direction; $\mathrm{C}$ - Principal stresses (destruction bottom layer). 
Table 1: Main results of structural analysis of buildings of synagogue.

\begin{tabular}{|c|c|c|c|c|}
\hline \multirow{2}{*}{ No } & \multirow{2}{*}{ Parameters } & \multicolumn{2}{|c|}{ Values } & \multirow{2}{*}{ Notes } \\
\hline & & Direction $\mathrm{x}$ & Direction y & \\
\hline 1 & 2 & 3 & 4 & 5 \\
\hline 1 & Total vertical load, $\mathrm{t}$ & \multicolumn{2}{|c|}{1450} & \\
\hline 2 & Total horizontal load, t & 135 & 139.9 & $Z=0.1$ \\
\hline 3 & Periods of free vibration, $\mathrm{s}$ & $\begin{array}{l}\mathrm{T}_{1}\left(\mathrm{~m}_{1}\right)=0.291 \\
\mathrm{~T}_{2}\left(\mathrm{~m}_{3}\right)=0.219 \\
\mathrm{~T}_{3}\left(\mathrm{~m}_{5}\right)=0.172\end{array}$ & $\begin{array}{l}\mathrm{T}_{1}\left(\mathrm{~m}_{1}\right)=0.354^{*} \\
\mathrm{~T}_{2}\left(\mathrm{~m}_{2}\right)=0.262 \\
\mathrm{~T}_{3}\left(\mathrm{~m}_{5}\right)=0.207 \\
\mathrm{~T}_{4}\left(\mathrm{~m}_{6}\right)=0.163\end{array}$ & $\begin{array}{l}\mathrm{m}_{\mathrm{i}}-\text { mode shape } \\
\text { *local fronton } \\
\text { vibrations }\end{array}$ \\
\hline 4 & Partial horizontal loads, $\mathrm{t}$ & $\begin{array}{l}\mathrm{Q}_{1 \mathrm{x}}\left(\mathrm{m}_{1}\right)=127.5 \\
\mathrm{Q}_{2 \mathrm{x}}\left(\mathrm{m}_{3}\right)=31.6 \\
\mathrm{Q}_{3 \mathrm{x}}\left(\mathrm{m}_{5}\right)=31.4\end{array}$ & $\begin{array}{l}\mathrm{Q}_{1 \mathrm{y}}\left(\mathrm{m}_{1}\right)=39.1^{*} \\
\mathrm{Q}_{2 \mathrm{y}}\left(\mathrm{m}_{1}\right)=132.3 \\
\mathrm{Q}_{3 \mathrm{y}}\left(\mathrm{m}_{5}\right)=16.5 \\
\mathrm{Q}_{4 \mathrm{y}}\left(\mathrm{m}_{6}\right)=23.2\end{array}$ & $\begin{array}{l}\text { *local fronton } \\
\text { vibrations }\end{array}$ \\
\hline 5 & $\begin{array}{l}\text { Max displacements of wall } \\
\text { top, } \mathrm{mm}\end{array}$ & $\mathrm{U}\left(\mathrm{m}_{1}\right)=8.99 *$ & $\mathrm{~V}\left(\mathrm{~m}_{2}\right)=22.3 * *$ & $\begin{array}{l}* \text { for wall sections } \\
\text { along axes } \mathrm{x} \text { and } \\
\mathrm{y}(\mathrm{h}=6.0-6.6) \\
* * \text { for fronton top }\end{array}$ \\
\hline 6 & $\begin{array}{l}\text { Values of internal forces in } \\
\text { specific structural elements }\end{array}$ & & & \\
\hline 6.1 & Fronton section of wall & & & \\
\hline $\begin{array}{l}6.1 . \\
1\end{array}$ & $\begin{array}{l}\text { Max stress of vertical } \\
\text { loads, } \mathrm{t} / \mathrm{M}^{2} \\
\text { Max moment, t.m/m }\end{array}$ & $\begin{array}{l}\mathrm{N}_{\mathrm{x}}=-6.0 \\
\mathrm{M}_{\mathrm{x}}= \pm 0.10\end{array}$ & $\begin{array}{l}\mathrm{N}_{\mathrm{y}}=+4.0 \\
\mathrm{M}_{\mathrm{y}}= \pm 0.05\end{array}$ & \\
\hline \multirow[t]{2}{*}{$\begin{array}{l}6.1 . \\
2\end{array}$} & \multirow[t]{2}{*}{$\begin{array}{l}\text { Max stress of seismic } \\
\text { loads, } \mathrm{t} / \mathrm{m}^{2} \\
\text { Max moment, } \mathrm{t} . \mathrm{m} / \mathrm{m} \\
\text { Shear forces, } \mathrm{t} / \mathrm{m} \\
\text { Principal stress, } \mathrm{t} / \mathrm{m}^{2} \\
\text { Horizontal forces, } \mathrm{t} / \mathrm{m}\end{array}$} & $\begin{array}{l}\mathrm{N}_{\mathrm{x}}=+1.8 \\
\mathrm{M}_{\mathrm{x}}=+1.1 \\
\tau_{\mathrm{xy}} *= \pm 1.0 \\
\mathrm{~N}_{1}=+2.4\end{array}$ & $\begin{array}{l}\mathrm{N}_{\mathrm{y}}=+0.64 \\
\mathrm{M}_{\mathrm{y}}=-2.2 \\
\tau_{\mathrm{xy}}= \pm 0.76 \\
\mathrm{~N}_{2}=-0.25\end{array}$ & \multirow[t]{2}{*}{$\begin{array}{l}\mathrm{Z}=0.1 \\
* \mathrm{~m}_{2} \\
\text { (middle layer) }\end{array}$} \\
\hline & & \multicolumn{2}{|c|}{$\mathrm{Q}_{\mathrm{x}}, \mathrm{Q}_{\mathrm{y}}=4.7$} & \\
\hline 1 & 2 & \multicolumn{2}{|c|}{3} & 4 \\
\hline 6.2 & Peripheral shell & & & \\
\hline \multirow[t]{2}{*}{$\begin{array}{l}6.2 . \\
1\end{array}$} & \multirow[t]{2}{*}{$\begin{array}{l}\text { Max stress of vertical } \\
\text { loads, } \mathrm{t} / \mathrm{M}^{2} \\
\text { Max moment, } \mathrm{t} . \mathrm{m} / \mathrm{m} \\
\text { Principal stress, } \mathrm{t} / \mathrm{M}^{2} \\
\text { Shear forces, } \mathrm{t} / \mathrm{m}\end{array}$} & $\begin{array}{l}\mathrm{N}_{\mathrm{x}}=+3.2 \\
\mathrm{~N}_{\mathrm{x}}=-6.6 \\
\mathrm{M}_{\mathrm{x}}= \pm 0.56 \\
\mathrm{~N}_{1}=+1.5\end{array}$ & $\begin{array}{l}\mathrm{N}_{\mathrm{y}}=-8.1 \\
\mathrm{~N}_{\mathrm{y}}=+3.2 \\
\mathrm{M}_{\mathrm{y}}= \pm 0.52 \\
\mathrm{~N}_{2}=-2.7\end{array}$ & \multirow[t]{2}{*}{ (middle layer) } \\
\hline & & \multicolumn{2}{|c|}{$\tau_{\mathrm{xy}}= \pm 6.0$} & \\
\hline \multirow[t]{2}{*}{$\begin{array}{l}6.2 . \\
2\end{array}$} & \multirow{2}{*}{$\begin{array}{l}\text { Max stress of seismic loads, } \\
\mathrm{t} / \mathrm{M}^{2} \\
\text { Max moment, } \mathrm{t} . \mathrm{m} / \mathrm{m} \\
\text { Principal stress, } \mathrm{t} / \mathrm{M}^{2} \\
\text { Horizontal forces, } \mathrm{t} / \mathrm{m} \\
\text { Shear forces, } \mathrm{t} / \mathrm{m}\end{array}$} & $\begin{array}{l}\mathrm{N}_{\mathrm{x}}= \pm 1.3 \\
\mathrm{M}_{\mathrm{x}}= \pm 0.12 \\
\mathrm{~N}_{1}=+0.20\end{array}$ & $\begin{array}{l}\mathrm{N}_{\mathrm{y}}= \pm 3.6 \\
\mathrm{M}_{\mathrm{y}}= \pm 0.36 \\
\mathrm{~N}_{2}=-1.50\end{array}$ & \multirow[t]{2}{*}{$\begin{array}{l}\mathrm{Z}=0.1 \\
\text { (middle layer) }\end{array}$} \\
\hline & & \multicolumn{2}{|c|}{$\tau_{\mathrm{xy}}= \pm 2.2$} & \\
\hline
\end{tabular}


Table 1: Continued.

\begin{tabular}{|c|c|c|c|c|}
\hline \multirow{2}{*}{ No } & \multirow{2}{*}{ Parameters } & \multicolumn{2}{|c|}{ Values } & \multirow{2}{*}{ Notes } \\
\hline & & Direction $\mathrm{x}$ & Direction y & \\
\hline 1 & 2 & 3 & 4 & 5 \\
\hline 7 & $\begin{array}{l}\text { Steel rods for arches } \\
\text { Tension force, } t \\
\text { Tension stress }, t / \mathrm{m}^{2}\end{array}$ & \multicolumn{2}{|c|}{$\begin{array}{l}\mathrm{T}_{\min }=-4.45 ; \mathrm{T}_{\max }=+4.31 \\
\mathrm{~N}_{\min }=7050 ; \mathrm{N}_{\max }=6896\end{array}$} & $\begin{array}{l}\text { for } Z=0.2 \\
\mathrm{~N}_{\min }=14100 \mathrm{t} / \mathrm{m}^{2} ; \\
\mathrm{N}_{\max }=13792 \mathrm{t} / \mathrm{m}^{2} \\
\mathrm{R}_{\mathrm{s}} \approx 16000 \mathrm{t} / \mathrm{m}^{2}\end{array}$ \\
\hline 8 & $\begin{array}{l}\text { Sculpture } \\
\text { Stress of seismic horizontal } \\
\text { force and dead load, } \mathrm{t} / \mathrm{m}^{2} \\
\text { Max horizontal force(Base } \\
\text { Shear force), } \mathrm{t} \\
\text { Dead load, } \mathrm{t} \\
\text { Frictional force }, \mathrm{t}\end{array}$ & \multicolumn{2}{|c|}{$\mathrm{N}_{\min }=-12.7 ; \mathrm{N}_{\max }=7.41$} & $\begin{array}{l}\text { Min-compression } \\
\text { Max-tension } \\
\mathrm{Z}=0.2 \\
\text { Increase of } \\
\text { seismic load } \\
\text { factor } \mathrm{R}_{\mathrm{p}}=2 \\
\text { Base shear } \\
\mathrm{Q}_{\mathrm{Rp}}=2 \times 0.295=0.5 \\
9 \mathrm{t}>\mathrm{F}_{\mathrm{f}}=0.21 \mathrm{t}\end{array}$ \\
\hline
\end{tabular}

increasing factor of seismic action is applied for the console non-bearing elements. As is seen from the analysis of the seismic resistance of decorative elements (sculptures, see Table 1, paragraph 8), such increase is necessary for securing the seismic resistance of the console elements.

\section{Experience}

On September 8, 2009, there was an earthquake in northern Georgia. The magnitude in the epicentre of the earthquake was 6.2. 1,400 houses were damaged or destroyed. The epicentre was $12 \mathrm{~km}$ from Oni which was the most damaged location (Fig. 13).

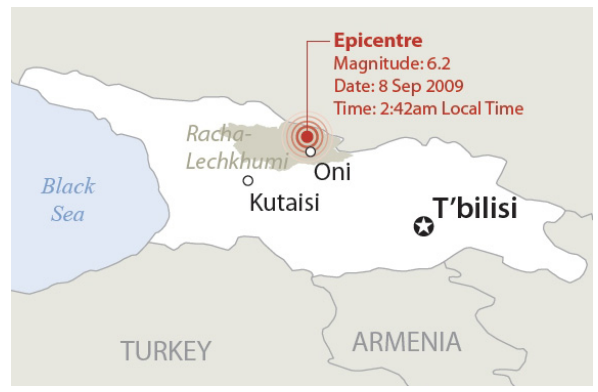

Figure 13: $\quad$ Seismic situation caused by the earthquake in Georgia, 2009.

The building of the synagogue in Oni survived this earthquake without any substantial damage caused. It proves the effectiveness of the strengthening and rehabilitation works in these buildings performed by us. 


\section{Conclusions}

1. As a result of the earthquake on April 29, 1991, the synagogue in Oni was damaged. Some structures, mainly console structures, collapsed.

2. Retrofitting of these structures was completed two years later. The estimation of seismic resistance and the strengthening was done using the method for estimation of structural seismic resistance of buildings. Afterwards, in order to investigate the behavior of a building during an earthquake a detailed analysis of seismic resistance was made using FEM. The results of such an analysis given here correspond to the behavior of the building during the earthquake closely enough which makes it possible to recommend successfully using FEM.

3 . The synagogue in Oni after the strengthening end restoration survived the Richter magnitude 6.2 earthquake in this region on September 8, 2009, without any substantial damage caused. Methods and techniques offered and applied for retrofitting the synagogue in Oni may be recommended for the strengthening and conservation of other historic structures.

\section{References}

[1] Krautheimer, R., Curčić, S., Early Christian and Byzantine architecture, Penguin Books Ltd.: Harmondsworth, Middlesex, England, 1986.

[2] Paret, T., Freeman, S., Searer, G., Hachem, M., Gilmarin, U., Seismic evaluation and strengthening of an historic synagogue using traditional and innovative methods and materials. Proc. $1^{\text {st }}$ European Conference on Earthquake Engineering and Seismology, Geneva, Switzerland, (SD-R) paper No 701, 2006.

[3] Repair and strengthening of historical monuments and buildings in urban nuclei. Building construction under seismic conditions in the Balkan region. UNDP/UNIDO project rep/79/015, Vienna, 1984.

[4] Sesigur, H., Celik, O.C., Cili, F., Repair and strengthening of ancient structures. Proc. $1^{\text {st }}$ European Conference on Earthquake Engineering and Seismology, Geneva, Switzerland, (SD-R) paper No. 1387, 2006.

[5] Rabin, I., Structural Analysis of Historic Buildings: Restoration, Preservation and Adaptive Application for Architects and Engineers. Wiley \& Sons, New-York, 2000.

[6] Protection of Historical Buildings PROHITECH 09. Proc. of the International conference on Protection of Historical Buildings, Prohitech 09, Rome, Italy, 21-24 June 2009.

[7] Danieli (Danielashvili), M., Gabrichidze, G., Goldman, A., Sulaberidse, O., Experience in restoration and strengthening of stone made ancient domes in seismic regions. Proc. $7^{\text {th }}$ US NCEE, Boston, Massachusetts, USA. Vol II: pp. 1167-1175, 2002.

[8] Danielashvili, M., Synagogue in Oni. In: Engineering Analysis of the Racha Earthquake Consequences in Georgia 1991, Metsniereba: Tbilisi, Georgia, 1996. (in Russian and English). 
[9] Sekhniashvili E.A., Danielasvili M.A., and Zhorzholadze T.A., Instruction for investigating the technical conditions and seismic stability of civil and public buildings in Georgia. Ministry of Architecture and Building, Academy of Sciences of Georgia, Tbilisi, 1992 (in Georgian).

[10] Danielasvili M. A. and Tchatchava T. N., A method for quantitative estimation of the earthquake resistance of buildings. Earthquake Engineering, 1, Moscow, pp. 14-16, 1999 (in Russian).

[11] Danieli), M. and Bloch, J., Evaluation of earthquake resistance of existing reinforced concrete buildings. Ariel University, Ariel, 2014.

[12] Danieli (Danielashvili), M. and Bloch, J., Evaluation of earthquake resistance and the strengthening of buildings damaged by earthquake. Proc. 1st European Conference on Earthquake Engineering and Seismology, Geneva, Switzerland, Paper No: 673 (SD-R), 2006.

[13] Levin M.S. and Danieli (Danielasvili) M.A., Framework of system evaluation and improvement for buildings, CoDesing. 2000 Adjunct Proc. Coventry University, U.K., pp. 209-214, 2000.

[14] IS 413. Israel Standard-413-1998, Design provisions for earthquake resistance of structures, Tel-Aviv, 1998 (in Hebrew). 